\title{
Coping With COVID-19: Learning From Past Pandemics to Avoid Piffalls and Panic
}

Daniel T. Halperin ${ }^{a}$

\section{Key Messages}

- As we wrestle with how best to mitigate COVID19 , it is imperative to concur on the likely main drivers of transmission (notably, infection clusters resulting from prolonged indoor respiratory exposure) in order to clearly explain risk and to determine the most effective, realistic behavioral and other means to reduce illness and mortality.

- At the same time, we must avoid generating irrational fear and maintain a broader perspective, including assessing the possibility for substantial unintended consequences from the response to the pandemic.

\section{UNCANNY SIMILARITIES WITH THE LAST MAJOR PANDEMIC}

I

n June 1981, when the first cases were reported of what became known as AIDS, I was living in the San Francisco Bay area. As the waves of death mounted, I volunteered at a hospice in Oakland, California, and later conducted epidemiological research at the University of California.

There are major differences between HIV and severe acute respiratory syndrome coronavirus 2 (SARS-CoV2 ) and their resulting pandemics (AIDS and coronavirus disease ([COVID-19]). However, I'm having déjà vu: from the devastating number of deaths and the pervasive atmosphere of confusion, fear, and often panic.

Tragically, political leaders from Ronald Reagan to Nelson Mandela were slow to respond to the AIDS epidemic. All sides engaged in acrimonious ideological warfare that often ignored the epidemiological evidence. In hindsight, health authorities also made some decisions-especially under the pressure of needing to act immediately - that led to suboptimal and ultimately costly outcomes. ${ }^{1,2}$ Policies often became hardwired

a Gillings School of Global Public Health, University of North Carolina, Chapel Hill, NC, USA.

Correspondence to Daniel Halperin (dhalpe@gmail.com). over time and difficult to walk back, even after new evidence appeared. Well-meaning but overly simplistic messages such as, "always use a condom with anyone or die" inadvertently created other problems. ${ }^{1,3,4}$ Earlier openness to innovative approaches, such as male circumcision and addressing sexual networks, could have saved many lives, particularly in sub-Saharan Africa. ${ }^{1,2,5}$ In subsequent years, as greater funding for research and treatment eventually poured in, a kind of "AIDS exceptionalism" also became imbedded. ${ }^{6}$

During the first years of the AIDS response, much was unknown regarding the causes and main modes of transmission. Yet, even after HIV was identified in 1983 and the basic science became clearer, a great deal of uncertainty, persecution of marginalized groups, and terror persisted. Rumors proliferated that anything from mosquitoes to using contaminated condoms to sharing toothbrushes were spreading the virus. In the 1990s, after Earvin "Magic" Johnson tested positive for HIV, counseling centers became overrun by the "worried well." ${ }^{, 13}$ Heterosexual college students flooded centers to get tested, petrified from having engaged in deep kissing or intimate touching "without protection," thereby diverting attention from those who were actually at significant risk of infection.

\section{CONFUSION AND PANIC RETURNS WITH THIS PANDEMIC}

With COVID-19, much remains unclear, but some basic facts are known and more emerge daily. Yet, a palpable climate of confusion and anxiety pervades. (One mindboggling indication is that the Johns Hopkins University Coronavirus Resource Center website is recording some 4 billion hits a day! ${ }^{7}$ ) Under such circumstances, fear is understandable and can help motivate behavior change. ${ }^{1,8}$ However, when fear becomes irrational or leads to panic, it often results in poor decision making and other unintended consequences. ${ }^{9,10}$ Moreover, there are troubling signs that we have failed to learn other important lessons from the previous pandemic, including the danger of polarized infighting. For example, politicians and the media as well as some medical experts are presenting us with a false dichotomy: having to 


It may be that
advanced age
alone, in the
absence of
preexisting
conditions, is less
of an independent
risk factor than
has been
assumed.

choose between recklessly abandoning mitigation efforts to reopen the economy versus rigidly continuing present lockdown measures.

The U.S. territory of Puerto Rico where I reside implemented a nearly complete shutdown in midMarch after the first death here (of an Italian cruise ship passenger). Since then, many people, convinced the virus is "everywhere" and infection is nearly unavoidable, won't leave their homes even to pick up groceries. When delivery services became overwhelmed, elderly and sick persons sometimes have not been able to obtain essential supplies. Most of those who do drive or go outdoors use masks (needlessly) even when far away from other people. Wearing masks in the hot, humid climate can be uncomfortable and has created issues, including elderly persons fainting while waiting in the sun for a long time to enter stores (which often only allow a handful of customers to enter at once). Until recently, joggers and others were stopped and occasionally fined by police for venturing outside or for violating the $7 \mathrm{pm}$ curfew, which remains in effect after nearly 3 months. (Even in most of the world's hardest-hit countries, such as Spain and Italy, people are now allowed outdoors to exercise.) Numerous restaurants, especially Asian-owned ones, have closed after losing takeout customers. Some stores require customers to wear gloves, despite evidence suggesting limited utility or that their use may actually increase risk of infection. ${ }^{11}$

\section{WHAT ARE THE MAIN RISK FACTORS FOR SEVERE OUTCOMES?}

It is probable that most infections occur from close exposure to coughing, sneezing, shouting, singing, or other direct and prolonged contact with an infected person.
In Puerto Rico, as in other parts of the world, many people (even many youth) with asthma are terrified of experiencing severe outcomes if they become infected with the virus, prompting shortages of inhalers and other critical supplies. The U.S. Centers for Disease and Prevention (CDC) website lists people with asthma near the top of those at risk of severe COVID-19 outcomes, even though only 1 clinical study has investigated whether a relationship exists and has found no link. ${ }^{12}$ Although other emerging data strongly appear to confirm the lack of an association, ${ }^{13}$ it is unclear whether the CDC will correct its public information.

What is clear, based on evidence from several countries (and despite media attention to statistically anomalous cases of healthy and younger victims), is that severe outcomes and deaths from COVID-19 are overwhelmingly associated with preexisting (and especially multiple) serious illnesses such as diabetes and heart disease, ${ }^{14-16}$ more so in men and particularly when exacerbated by obesity and smoking. ${ }^{17,18}$

Indeed, it may be that advanced age alone, in the absence of such predisposing conditions, is less of an independent risk factor than has been assumed. Firstly, the elderly are more likely to have chronic illnesses, which confounds the association between outcomes and age. Moreover, the fact that between $96 \%$ (in the United States ${ }^{16}$ ) and more than $99 \%$ (in Italy ${ }^{14}$ ) of COVID-19-related deaths, at any age, have occurred in persons with preexisting conditions could suggest that even very old but otherwise healthy people may not be at greatly elevated risk of dying from the disease. Further research and analysis, including assessing whether the important angiotensin-converting enzyme 2 protein (ACE-2) is more prevalent in the elderly ${ }^{19}$ could help explain the often higher infection (not only higher mortality) rates in older populations. ${ }^{20}$ In any case, such data underscore the ongoing need in general to prioritize preventing chronic diseases, which kill more than 40 million people annually (over $80 \%$ in lower- and middleincome countries), ${ }^{21}$ and to address underlying conditions such as obesity and smoking. ${ }^{22,23}$

\section{CLEAR EVIDENCE-BASED INFORMATION IS OFTEN LACKING}

Regarding COVID-19 prevention, it is imperative for experts to agree on what are the likely main transmission routes and to carefully determine which are, accordingly, the most effective (and realistically achievable) behavioral and other ways to reduce morbidity and mortality. It is probable that, as with other respiratory illnesses such as influenza, most COVID-19 infections occur from close exposure to coughing, sneezing, shouting, singing, or other direct and relatively prolonged contact with someone who is symptomatic or presymptomatic. (There is evidence that some asymptomatic carriers are contagious, but from existing studies they appear not to represent a very substantial proportion of total COVID-19 transmission.)

In February, a team of World Health Organization (WHO) researchers led by David Heymann investigated the outbreak in Wuhan, China, and concluded that the large majority of transmission events occurred within indoor clusters $^{24}$ between family members (accounting for $75 \%-85 \%$ of estimated infections) and coworkers, with no identified cases of child-to-adult transmission identified. ${ }^{15}$ In addition, some data suggest that severity of outcomes is associated with initial exposure 
viral-load levels. ${ }^{24-26}$ Moreover, it increasingly appears that infection risk from contaminated surfaces has been at least somewhat overstated, as the CDC recently acknowledged. ${ }^{27}$ Indeed, it is conceivable that future science historians may conclude that many current COVID-19 prevention strategies had little if any impact, particularly because they targeted drivers of spread accounting for no more than a small proportion of total infections.

\section{HIGH RISK, LOW RISK, OR NO RISK OF TRANSMISSION}

As some experts eventually did with HIV, ${ }^{1,4}$ they could also help the public distinguish between those behaviors and situations posing the highest risk for COVID-19 infection, those of likely lower risk (such as the virus lingering on hard surfaces for extended periods), and those of highly unlikely or no risk (such as being outdoors with no one else around). Although the CDC has posted some basic guidance on its website (in the Frequently Asked Questions section) regarding how COVID-19 is mainly transmitted, the public would benefit from a more clearly communicated ${ }^{28}$ and much more robust public information campaign (e.g., including the virtual equivalent of placing a leaflet under every U.S. resident's door). This would help reduce time and attention spent addressing lowrisk concerns, such as when healthy people avoid leaving home for necessary activities even if carefully taking precautions.

There is a crucial distinction between risk of indoor transmission-where physical distancing (whether mandated or voluntary) and perhaps other measures ${ }^{28,29}$ are critical-versus risk of outdoor transmission, which is far lower (possibly by an order of magnitude) for various reasons, including dissipation of droplets in the air ${ }^{28,30}$ and the deactivating effects of ultraviolet radiation and heat. ${ }^{31-33}$ A contact tracing study from China found that $80 \%$ of infections involved household members and 34\% involved mass transit (multiple potential transmission routes were considered), whereas only a single infection event of the 7,324 cases investigated was linked to casual outdoor transmission. ${ }^{28,30,34}$

Although politicians and the media have been obsessed with the danger of frolicking on beaches (or of participating in protest gatherings), a vastly greater risk is the common (public health) admonition for sick persons to remain home as long as possible before seeking hospital care, without providing access to alternative, clinically-provisioned quarantine residences, as several Asian countries and Iceland have successfully instituted. ${ }^{35-37}$ Delays in seeking care not only diminish survival chances but also expose household members to significant infection risk. ${ }^{14,35,36,38}$

\section{IS 6 FEET DISTANCING STRICTLY NECESSARY?}

One example of inconsistent public health messaging is that European and Asian authorities and the WHO recommended physical distancing based on data that droplets containing the virus had been identified almost a meter away from coughing individuals. In the United States, for some reason 1 meter was initially translated into 5 feet and subsequently became "over 6 feet." Although perhaps arguably not the highest priority, it would be useful for the CDC and other experts to determine whether such abundance-of-caution guidance is worth maintaining or perhaps is not scientifically warranted, and may inadvertently feed excessive concern. (In fact, the entire concept of physical or "social" distancing is not specifically relevant to transmission risk, primarily related to respiratory droplets: the pertinent issue is not the distance per se between people's bodies but rather between their faces, particularly if unmasked. For example, if 2 people are positioned back-to-back, then obviously the distance can safely be much less.)

This issue of distancing is particularly relevant as weather improves and outdoor exercise becomes more common, as many health departments ${ }^{28,30,39}$ encourage people to do (even though a hypothetical model based on untested assumptions sparked alarm by suggesting that joggers or cyclists could spread the virus over greater distances ${ }^{40}$ ). And critically, as the economy begins to reopen, it would be especially challenging for some businesses (and eventually schools) to adhere strictly to a 6-foot rule. This could be particularly excessive for outdoor activities, including construction, farming, recreation, and outdoor dining. It is certainly more practical to maintain a distance of about 3 feet than 6 feet in many situations, such as grocery shopping (where interactions are typically brief) or while strolling with a companion.

\section{COVID-19 AND CHILDREN: MUST SCHOOLS REMAIN CLOSED?}

Indeed, it is likely that more "surgical"-more carefully targeted and realistic, evidence-based approaches ${ }^{4,41-43}$ — could be similarly efficacious as more extreme isolation strategies that have been

\section{Future historians may conclude that many current prevention strategies had little impact because they targeted unlikely drivers of infection.}

\section{The pertinent factor is not the physical distance between people's bodies, but rather the distance between their faces.}

\section{There is a crucial distinction between risk of indoor transmission, where physical distancing is critical, versus the risk of outdoor transmission, which is far lower.}


widely implemented. For example, Singapore had initially achieved a notably effective response without shutting schools. ${ }^{44}$ (However, subsequently there was a surge in cases due to an outbreak in crowded migrant-worker dormitories.) Taiwan, which never closed its schools, has continued to report very few cases.

Similar to the first severe acute respiratory

Growing evidence suggests that children are less likely to become infected. Even if they become infected, they are less contagious than adults. syndrome (SARS) epidemic in 2002-2004, ${ }^{45,46}$ the vast majority of children infected with SARSCoV-2 escape severe outcomes. There has been much media attention to multisystem inflammatory syndrome in children (MIS-C), which has features similar to Kawasaki disease. However, of the more than 7 million COVID-19 infections reported worldwide to date, only a few hundred cases of MIS-C have been identified so far. ${ }^{47,48}$ (Although the usual Kawasaki disease is more common in East Asia, in the United States about 5,000 cases occur annually. ${ }^{48}$ ) Of more than 400,000 COVID-19 deaths reported worldwide, some 20 children are known to have died, about half of them in the United States and the rest in Europe. By comparison, more than 200 children died last year from the flu in the United States alone, along with some 10,000 others from various childhood diseases. ${ }^{49}$ Further contextualizing the MIS-C and other childhood deaths from COVID-19, in the United States, per-capita mortality in persons aged 85 years and older is 2,000 times higher than in children aged 15 years and younger. $^{50}$ (An intriguing question posed by some researchers is whether MIS-C is definitely or always caused by COVID-19, considering that in some cases up to one-third of afflicted children have tested negative for COVID-19, both on polymerase chain reaction and antibody tests. ${ }^{51}$ ) Although the emerging MIS-C must be closely monitored, as with Kawasaki disease most cases appear to recover fairly rapidly, especially if detected and treated early. ${ }^{46-48}$

Because young people typically come in contact with many other children and adults, they are often efficient spreaders of respiratory pathogens. However, growing evidence suggests that, as with the earlier SARS, ${ }^{45,46}$ children are less likely to become infected with SARS-COV-2. ${ }^{52-58}$ According to the CDC, only about $1.5 \%$ of U.S. cases of COVID-19 have been reported in persons aged 18 years or younger. ${ }^{59}$ Researchers theorize that previous exposure to other coronaviruses (e.g., those producing many of the common colds frequently acquired by children) may confer some partial resistance to SARS-CoV-2. ${ }^{47,52,54}$ Interestingly, when blood samples collected before fall 2019 (i.e., before people began getting infected) were analyzed, about half the people studied appeared to already have some protective T-cell immunity to the new virus, resulting from past exposure to other coronaviruses. $^{60}$ Importantly, young people also produce smaller amount of the aforementioned ACE- 2 protein, a critical nasal cell entry point for both SARS viruses. $^{19,47,52}$

Moreover, the evidence suggests that even when children do become infected, they are probably considerably less contagious than adults. ${ }^{46,53-58,62}$ A recent German study found viral loads in infected children at levels comparable to adults. However, the number of children studied was very small and other methodological concerns have been raised. More importantly, although for some pathogens (such as HIV) viral load is highly associated with infectivity, the implications of viral load for COVID-19 clinical progression and contagiousness remain unclear. $^{53,54,61}$ Because the many asymptomatic youth infected with COVID-19 are not coughing or sneezing, they emit far fewer infectious droplets. And remarkably, contact tracing studies conducted in China, Iceland, Netherlands, and United Kingdom have failed to identify a single case of child-toadult infection of thousands of transmission events analyzed. ${ }^{15,36,52-57}$ A review of household transmission studies from several Asian countries concluded that less than $10 \%$ of household clusters involved a child index case, $^{62}$ and a analysis of different COVID-19 interventions in the United States found no evidence for the impact of school closures. ${ }^{63}$

It should be noted that some of these data probably underestimate children's actual contagiousness, as they were collected after lockdowns and other mitigation measures had been implemented. However, the striking findings from the contact tracing studies in particular, as well as the evidently significant biological differences between COVID-19 and other respiratory pathogens, suggest that children are not major sources of infection, especially as compared to the common cold strains of coronaviruses, for example.

Even without the substantial amount of data that emerged subsequently (which presumably would have reduced the predicted impact of school closures), in March 2020, modelers from the Imperial College of London estimated that closing schools might prevent only $2 \%-4 \%$ of premature deaths in the United Kingdom (i.e., predominantly of older adults with predisposing conditions such as chronic diseases, obesity, and smoking, who could become directly or indirectly infected from schoolchildren. ${ }^{64}$ In contrast, the modelers estimated that $17 \%-21 \%$ of total deaths can be prevented from self-quarantining at home. 
In Denmark, Norway, and New Zealand, where schools reopened in April 2020, the numbers of new COVID-19 cases have continued to fall, similar to trends in Finland, France, Germany, Netherlands, and Vietnam, where schools all reopened in mid-May or earlier (though cases have increased in Madagascar, but perhaps not mainly due to reopening schools). It will, of course, be vitally important to implement adequate testing and safety measures for teachers and other school employees ${ }^{68,69}$ and to closely monitor the data as schools also begin reopening in Australia, Israel, Japan, and elsewhere (even as some U.S. school districts and colleges have announced that fall 2020 instruction will be conducted strictly online). (In Switzerland, health authorities also announced permission for grandparents to hug their young grandchildren. ${ }^{70}$ )

Certainly, as decisions are made regarding the reopening of schools, it must be taken into account that school closures have been depriving over a billion students worldwide of essential classroom learning, vital social connections, and physical activity. In addition, socioeconomic disparities are increasingly exacerbated, as some families have the technological, parental academic assistance, and other resources to enhance online learning, while less privileged children fall further behind. $^{54,55,58,71}$ Other huge consequences of school closures include documented surges in child abuse; hunger from missed subsidized meals; and greater anxiety, depression and isolation, which often are most acutely experienced by students with autism, Down syndrome, attentiondeficit/hyperactivity disorder and other special needs challenges. ${ }^{71-80}$

\section{- ONE ALTERNATIVE TO LOCKDOWN: MOVING TOWARD HERD IMMUNITY?}

Although many experts continue to believe that stayin-place measures are needed to flatten the curve, others have proposed a Phase 2 alternative-instead of attempting to prevent any new infections-of essentially allowing younger and healthier people to gradually return to work and school, based on a herd-immunity strategy. ${ }^{43,44,81,82}$ Although many of them could eventually become infected, most individuals would be expected to experience relatively mild to moderate symptoms and, ideally after self-quarantining, would effectively be "naturally vaccinated" (i.e., they would presumably no longer be contagious, for perhaps a year or more). Such an approach assumes, of course, that reinfection is uncommon, which-although most experts believe is quite probably the case-remains unconfirmed. ${ }^{83,84}$ Note that if previous infection does not confer immunity, it may prove very difficult to develop a vaccine that does so.

This sort of herd-immunity approach could be strongly enhanced by large-scale antibody testing to identify previous infection, as China, Germany, Spain, United Kingdom, and some U.S. locales have begun to implement. ${ }^{85,86}$ Crucially, we must determine how best to isolate or otherwise protect the most vulnerable populations from infection-certainly no easy task. If it were to be the case, as previously discussed, that elderly but otherwise healthy people are not actually at considerably greater risk of severe illness or death, then clearly this would make the challenge somewhat less daunting. However, the evidence is not yet sufficient to base policy on this still-hypothetical possibility.

Although obviously far from ideal, something akin to such an alternative approach may emerge (including perhaps in some lower-income regions) as one of the least terrible, more realistic longer-term alternatives, until a vaccine is available. Interest in such strategies is intensified by the potential for a resurgence of infections once containment measures are eased, including a possible second wave in late 2020 and early 2021 . Outcomes will need to be rigorously assessed in places like Sweden, where despite most businesses and schools having stayed open, COVID-19 deaths have been declining, though not as sharply as in most other European countries. ${ }^{87}$

\section{WHAT CAN WE LEARN FROM PLACES THAT DID NOT IMPOSE A FULL LOCKDOWN?}

Ongoing attention has focused on Sweden's percapita death rate being much higher than in other Scandinavian countries. However, a crucial difference is that in Sweden most reported cases (not only deaths) have occurred heavily among the elderly, ${ }^{20}$ particularly those residing in long-term care homes-similarly to the situation in Belgium, France, Italy, Netherlands, Spain, and the United Kingdom. ${ }^{50,87,88}$ Those countries (and, for example, the New York/New Jersey area) all have higher reported death rates than Sweden, despite tightly locking down since at least late March 2020. That Sweden's COVID-19 mortality is lower than in those European countries becomes even more evident if comparing via excess mortality (current deaths compared to typical levels in preceding

\section{If previous infection does not provide immunity, vaccines are also unlikely to work.}

Crucially, we must determine how best to isolate or otherwise protect the most vulnerable populations from infectioncertainly no easy task.

\section{School closures have deprived over a billion students of academic progress, social connections, physical activity, and subsidized meals.}


The urge to apply an either/or, onesize-fits-all approach should be resisted.

\section{It is noteworthy that in the 5 U.S. states that never imposed stricter isolation measures, observable increases in new cases have not occurred.}

years) instead of relying on official mortality data. Belgium and Sweden are 2 European countries that appear to have maintained near completely accurate data on COVID-19 mortality. ${ }^{89}$ Thus, although official statistics would suggest, for example, that Belgium's death rate is not only the world's highest but is about double that of neighboring Netherlands', if instead the comparison is based upon excess mortality, the 2 countries' actual death rates appear much more similar. ${ }^{89}$ (It could, therefore, be mistaken to conclude that Belgium's mitigation efforts have necessarily been inferior to the Netherlands' since the more pertinent explanation may simply involve an issue of data reporting quality.) Very importantly, all of the aforementioned places, including Sweden, have failed to implement adequate control measures in elderly residences. ${ }^{50,87,88}$ Whereas in Denmark and Norway, similar to the situation in Germany, Japan, and South Korea, a much larger proportion of infections has for some reason occurred in relatively younger people, ${ }^{20}$ consequently resulting in considerably lower COVID-19 death rates.

Apparently also very salient, if rarely mentioned, is that recent immigrants in Sweden have suffered disproportionally far greater infection and mortality rates, reportedly due in part to insufficiently targeted prevention campaigns. ${ }^{90,91}$ By one estimate, perhaps $40 \%$ of all COVID-19 deaths in the capital city, Stockholm, have been solely among Somali refugees (who comprise a minority of foreign-born immigrants in the city, after Iraqis, Syrians, and Afghans, in that order). ${ }^{90}$ NonEuropean residents also comprise-differently than the case elsewhere in Scandinavia-the majority of the country's nursing home employees. ${ }^{90}$ Although certainly understandable, the possible fear by the Swedish government of a xenophobic or Islamophobic backlash may, however, have resulted in grave public health consequences, reminiscent of prevention campaigns during the earlier AIDS years that shifted attention, also understandably but similarly deleteriously, away from those at highest risk to avoid homophobia and discrimination against marginalized groups. ${ }^{1,3}$

It also appears noteworthy that in the 5 U.S. states that never imposed stricter isolation measures, ${ }^{92}$ observable increases in new cases have not occurred, as compared to demographically and otherwise similar neighboring rural states that implemented tight lockdowns. ${ }^{93}$ This observation is consistent with the fact that modeling predictions in late April 2020 of a sharp uptick of death across the United States, ${ }^{94}$ as many (largely rural) states began reopening, turned out to be considerably overdrawn. ${ }^{93,95}$

A key implication of the experience from the 5 non-lockdown U.S. states and Sweden is not that death rates in those places have been lower than elsewhere, but if outcomes generally have not been worse, this suggests that similar results may be achieved at a less drastic economic and societal cost. (In the case of Sweden, a fairer comparison would be to more epidemiologically similar European countries, rather than utilizing the "ecological fallacy" of comparing its experience only to the other Scandinavian nations.) In any case, the urge to apply an either/or, one-size-fitsall approach, which also hampered the response to AIDS and some other past health crises, $1,2,4,5$ should be questioned, including in lower- and middle-income world regions. ${ }^{93,96-100}$

\section{UNINTENDED CONSEQUENCES OF THE GLOBAL LOCKDOWN COULD BE MASSIVE}

It is crucial that an evidence-based and transparent debate underpin decisions, ${ }^{41}$ obviously taking into consideration the unprecedented consequences of financial collapse and lost income resulting from a prolonged economic shutdown, $9,44,82,99-105$ as most painfully experienced among socioeconomically disadvantaged populations. ${ }^{106}$ Such disruptions are being felt most dangerously in the lowest-income regions of subSaharan Africa and South Asia, where the prospect looms for unintended consequences of harrowing proportions. ${ }^{73,96-102,105,107}$ These include potentially vast increases in deaths from malaria, tuberculosis, measles, polio, diarrheal and other diseases, and malnutrition, as vaccination, maternal and child health, family planning, and other basic services are suspended due to lockdowns or are deprioritized while health efforts increasingly focus on COVID-19. ${ }^{71,96-99,108-113}$ Considering that young children are likely to be particularly impacted, this would represent an even greater magnitude of devastation if measured in terms of years-of-life-lost, and not only via crude mortality numbers.

The catastrophic number of deaths directly resulting from COVID-19-which eventually may eclipse the estimated 1 million from the "Hong Kong" flu in 1968-1969,"14 (when the world's population was less than half of today's) -along with the many who could suffer long-term sequelae, ${ }^{115,116}$ must be considered alongside the increased mortality and compromised outcomes for 
the numerous persons suffering from non-COVID19-related cardiac arrest, stroke, appendicitis, and other urgent conditions who have been denied medical attention or have delayed treatment for fear of seeking hospital care. ${ }^{38,117-119}$

Moreover, job losses and mass school closures from the lockdowns are intensifying socioeconomic disparities, including potentially dooming hundreds of millions of children to long-term educational, psychosocial, and vocational disadvantages. $^{54,55,58,64,71,75,78,99}$ Policy makers, such as the WHO, foreign donors, and local governments, appear to be making enormously consequential decisions without fully taking into account some key demographic as well as potentially significant climate $31-33,120$ and childhood vaccinerelated $^{121,123}$ differences between lower-income regions (characterized typically by more rural populations and an age pyramid dominated by young people) and Europe and North America (more urban, older, and often more obese populations, thus probably much more vulnerable to COVID-19 mortality). ${ }^{96-99,124,125}$

Furthermore, it is critical to consider the consequences of remaining inside (often cramped) living quarters for extended durations, including reported increases in domestic violence ${ }^{126-128}$ and child abuse, ${ }^{72-74,127}$ as well as other physical and mental health issues related to chronic diseases $^{30}$; obesity $^{79}$; social isolation ${ }^{10}$; anxiety, depression, and suicide $10,30,39,75-78$; obsessivecompulsive disorder ${ }^{129}$; poisoning from overuse of toxic cleaning products ${ }^{10}$; and autism, attentiondeficit/hyperactivity disorder, and other developmental challenges. ${ }^{80}$ As has occasionally occurred with other health crises such as HIV/AIDS, ${ }^{1,6}$ we must not lose sight of the bigger picture. It is sadly possible, especially in the lowest-income regions, that the remedy could be worse-perhaps tragically even far worse - than the disease itself.

Acknowledgments: The following individuals generously contributed to the formulation, refinement, and editing of this article: Coloma Araujo, Mark Tilton, Glenn Post, Patricia Rice Doran, David Wolfson, Robert Bailey, Roy Jacobstein, Norman Hearst, Erin Bromage, Carla Schierholt, Khalidah Bello, Lee Ross, Helen Epstein, Arthur Allen, Craig Timberg, Lewis Lucke, John Stanback, Edward Green, Gregg Gonsalves, Richard Cash, and Jim Shelton.

Competing interests: None declared.

\section{REFERENCES}

1. Timberg C, Halperin D. Tinderbox: How the West Sparked the AIDS Epidemic and How the World Can Finally Overcome It. New York: Penguin Books; 2012.

2. Epstein $\mathrm{H}$. The Invisible Cure: Why We Are Losing the Fight Against AIDS in Africa. New York: Farrar, Straus, \& Giroux; 2007.
3. Roiphe K. Last Night in Paradise: Sex and Morals at the Century's End. New York: Little, Brown \& Co.; 1997.

4. Marcus J. Quarantine fatigue is real. The Atlantic. May 1 1, 2020. Accessed May 26, 2020. https://www.theatlantic.com/ideas/ archive/2020/05/quarantine-fatigue-real-and-shaming-peoplewont-help/61 1482/

5. Potts M, Halperin DT, Kirby D, et al. Public health. reassessing HIV prevention. Science. 2008;320(5877):749-750. CrossRef. Medline

6. Halperin D. Putting a plague in perspective. New York Times. January 1, 2008. Accessed May 26, 2020. https://www. nytimes. com/2008/01/01/opinion/01 halperin.html

7. Timberg C. Death counts become the rhythm of the pandemic in the absence of national mourning. Washington Post. May 24, 2020. Accessed May 26, 2020. https://www.washingtonpost.com/ technology/2020/05/24/death-counts-become-rhythmpandemic-absence-national-mourning/

8. Witte M, Allen M. A meta-analysis of fear appeals: implications for effective public health campaigns. Health Educ Behav. 2000; 27 (5):591-615. CrossRef. Medline

9. Stephens B. It's dangerous to be ruled by fear. New York Times. March 20, 2020. Accessed May 26, 2020. https://www.nytimes. com/2020/03/20/opinion/coronavirus-data.html

10. Ripley A. Five ways to conquer your covid- 19 fears. Washington Post. April 6, 2020. Accessed May 26, 2020. https://www. washingtonpost.com/opinions/2020/04/06/five-ways-conqueryour-covid-19-fears/

11. Gallagher S. Coronavirus: can latex gloves protect you from catching deadly virus? The Independent. May 6, 2020. Accessed May 26, 2020. https://www.independent.co.uk/life-style/healthand-families/coronavirus-do-gloves-work-stop-virus-spreadsymptoms-outbreak-a9362871.html

12. Zhang JJ, Dong X, Cao YY, et al. Clinical characteristics of 140 patients infected with SARS-CoV-2 in Wuhan, China. Allergy. 2020; Published online February 19, 2020. CrossRef. Medline

13. Hakim D. Asthma is absent among top Covid-19 risk factors, early data shows. New York Times. April 16, 2020. Accessed May 26, 2020. https://www.nytimes.com/2020/04/16/health/ coronavirus-asthma-risk.html

14. Ebhardt T, Remondini C, Bertacche M. $99 \%$ of those who died from virus had other illness, Italy says. Bloomberg News. March 18, 2020. Accessed May 26, 2020. https://www.bloomberg.com/ news/articles/2020-03-18/99-of-those-who-died-from-virushad-other-illness-italy-says

15. World Health Organization (WHO). Report of the WHO-China Joint Mission on Coronavirus Disease 2019 (COVID-19). Published February 24, 2020. Accessed May 26, 2020. https://www.who. int/docs/default-source/coronaviruse/who-china-joint-missionon-covid-19-final-report.pdf

16. Garg S, Kim K, Whitaker M. Hospitalization rates and characteristics of patients hospitalized with laboratory-confirmed coronavirus disease 2019-COVID-NET, 14 states, March 1-30, 2020. MMWR Morb Mortal Wkly Rep. 2020; 69(15);458-464. CrossRef. Medline

17. Forrest A. Coronavirus: obesity doubles risk of needing hospital treatment, study suggests. The Independent. May 7, 2020. Accessed May 26, 2020. https://www.independent.co.uk/news/ health/coronavirus-obesity-doubles-risk-hospital-treatment-covid19-a9503196.html

18. Patanavanich R, Glantz SA. Smoking is associated with COVID-19 progression: a meta-analysis. Preprint. Posted online April 16, 2020. medRxiv. CrossRef

19. Patel AB, Verma A. Nasal ACE2 Levels and COVID-19 in children. JAMA. Published online May 20, 2020. CrossRef. Medline 
20. Statista.com. Number of coronavirus cases by age group (for various countries); May 2020. Accessed May 26, 2020. https:// www.statista.com/topics/5994/the-coronavirus-disease-covid19-outbreak/

21. United Nations News. Chronic illnesses: UN stands up to stop 41 million avoidable deaths per year. UN News. September 27, 2018 Accessed May 26, 2020. https://news.un.org/en/story/2018/ 09/1021132

22. Finkelstein, EA, Trogdon JG, Cohen W, Dietz W. Annual medical spending attributable to obesity: payer-and service-specific estimates. Health Aff. 2009;28(5):w822-w831. CrossRef. Medline

23. Halperin D. Puerto Rico's man-made disasters will kill more people than natural catastrophes. Miami Herald. January 20, 2020. Accessed May 26, 2020. https://www.miamiherald.com/ opinion/op-ed/article239463738.html

24. Little L, Read RC, Amlôt R, et al. Reducing risks from coronavirus transmission in the home-the role of viral load. BMJ. 2020; 369 . CrossRef. Medline

25. Camero K. How long you are exposed to coronavirus can determine if you get sick, experts say. Miami Herald. May 19, 2020. Accessed June 8, 2020. https://www.miamiherald.com/news/ coronavirus/article242846836.html

26. Kolata $G$. Why are some people so much more infectious than others? New York Times. April 12, 2020. Updated April 13, 2020 https://www.nytimes.com/2020/04/12/health/coronavirussuperspreader-why-infectious.html

27. Guarino B, Achenbach J. Virus 'does not spread easily' from contaminated surfaces or animals, revised CDC website state. Washington Post. May 21, 2020. Accessed May 26, 2020. https://www.washingtonpost.com/health/2020/05/21/virusdoes-not-spread-easily-contaminated-surfaces-or-animalsrevised-cdc-website-states/

28. Bromage E. The risks: know them, avoid them. Erin Bromage: COVID-19 Musings blog. May 6, 2020. Updated May 20, 2020 Accessed May 26, 2020. https://erinbromage.wixsite.com/ covid19/post/the-risks-know-them-avoid-them

29. Ontario Agency for Health Protection and Promotion (Public Health Ontario). Review of "COVID-19 outbreak associated with air conditioning in restaurant, Guangzhou, China, 2020." Toronto, Canada: Queen's Printer for Ontario; 2020. https://www. publichealthontario.ca/-/media/documents/ncov/research/ research-covid-19-outbreak-air-conditioning-restaurantguangzhou.pdf

30. Miller AM. Stop shaming people for going outside. The risks are generally low, and the benefits are endless. Business Insider. Apr 25, 2020. Accessed May 26, 2020. https://www. businessinsider. $\mathrm{com} /$ you-can-still-go-outside-while-quarantining-sheltering-inplace-2020-4

31. Yudistira N, Sumitro SB, Nahas A, Riama NF. UV light influences covid-19 activity through big data: trade-offs between northern subtropical, tropical, and southern subtropical countries. Preprint. Posted online May 22, 2020. medRxiv. CrossRef

32. Bukhari $Q$, Jameel $Y$. Will coronavirus pandemic diminish by summer? Massachusetts Institute of Technology. March 17, 2020. Updated April 18, 2020. CrossRef

33. Wu Y, Jing W, Liu J, et al. Effects of temperature and humidity on the daily new cases and new deaths of COVID-19 in 166 countries. Sci Total Environ. 2020;729:139051. CrossRef. Medline

34. Qian H, Miao T, Liu L, Zheng X, Luo D, Li Y. Indoor transmission of SARS-CoV-2. Preprint. Posted online April 7, 2020. medRxiv. CrossRef

35. Yglesia $M$. The successful Asian coronavirus-fighting strategy America refuses to embrace. Vox. April 28, 2020. Accessed June 8, 2020. https://www.vox.com/2020/4/28/21238456/ centralized-isolation-coronavirus-hong-kong-korea
36. Kolbert E. How Iceland beat the coronavirus. New Yorker. June 1, 2020. Accessed June 8, 2020. https://www.newyorker.com/ magazine/2020/06/08/how-iceland-beat-the-coronavirus

37. Acemoglu D, Chernozhukov V, Werning I, Whinston MD. Multi-risk SIR model with optimally targeted lockdown. Cambridge, MA: National Bureau of Economic Research. 2020; Working Paper 27102. CrossRef

38. Li W, Zhang B, Lu J, et al. The characteristics of household transmission of COVID-19. Clin Infect Dis. Published online April 17, 2020;ciaa450. CrossRef. Medline

39. Popkin G. Don't cancel the outdoors; we need it to stay sane. Washington Post. March 20, 2020. Accessed May 26, 2020. https://www.washingtonpost.com/outlook/2020/03/24/dontcancel-outdoors-we-need-them-stay-sane/

40. Blocken B, Malizia F, van Druenen, T, Marchal T. Towards aerodynamically equivalent COVID-19 $1.5 \mathrm{~m}$ social distancing for walking and running. 2020. Accessed May 26, 2020. http://www. urbanphysics.net/Social\%20Distancing\%20v20_White_Paper.pdf

41. Zakaria $F$. The pandemic is too important to be left to the scientists. Washington Post. April 30, 2020. Accessed May 26, 2020. https://www.washingtonpost.com/opinions/itll-take-more-thanjust-scientists-to-stem-this-pandemic/2020/04/30/9eel daf68bld-1 lea-9dfd-990f9dcc7lfc_story.html

42. Leung G. Lockdown can't last forever: here's how to lift it. New York Times. April 6, 2020. Accessed May 26, 2020. https://www. nytimes.com/2020/04/06/opinion/coronavirus-end-socialdistancing.html

43. Katz D. Is our fight against coronavirus worse than the disease? New York Times. March 20, 2020. Accessed May 26, 2020. https://www.nytimes.com/2020/03/20/opinion/coronaviruspandemic-social-distancing.html

44. Osterholm MT, Olshaker M. Facing covid-19 reality: a national lockdown is no cure. Washington Post. March 21, 2020. Accessed May 26, 2020. hitps://mww.washingtonpost.com/opinions/ 2020/03/21/facing-covid-19-reality-national-lockdown-is-nocure/

45. Stockman $\sqcup$, Massoudi MS, Helfand R, et al. Severe acute respiratory syndrome in children. Pediatr Infect Dis J. 2007;26(1):68-74. CrossRef. Medline

46. Wu KJ. The coronavirus spares most kids. These theories may help explain why. National Geographic. March 25, 2020. Accessed May 26, 2020. https://www.nationalgeographic.com/science/ 2020/03/coronavirus-spares-most-kids-these-theories-may-helpexplain-why/

47. Verdoni L, Mazza A, Gervasoni A, et al. An outbreak of severe Kawasaki-like disease at the Italian epicentre of the SARS-CoV-2 epidemic: an observational cohort study. Lancet. 2020; Published online May 13, 2020. CrossRef

48. Barber $\mathrm{G}$. What's the strange ailment affecting children with Covid19? Wired. May 15, 2020. https://www. wired.com/story/whatsthe-strange-ailment-affecting-kids-with-covid-19/

49. Cunningham RM, Walton MA, Carter PM. The major causes of death in children and adolescents in the United States. NEngl J Med. 2018;379(25):2468-2475. CrossRef. Medline

50. Roy A. $43 \%$ of COVID- 19 deaths are in nursing homes and assisted living facilities housing $0.6 \%$ of U.S. Forbes. May $26,2020$. Accessed May 26, 2020. https://wnw. forbes.com/sites/ theapothecary/2020/05/26/nursing-homes-assisted-livingfacilities-0-6-of-the-u-s-population-43-of-u-s-covid-19-deaths/\# ead 4 edf7 $4 \mathrm{cdb}$

51. de Benito E. Los niños tienen menos receptores en la nariz para que el coronavirus penetre en el organismo. El País. May 21, 2020. Accessed May 26, 2020. https://elpais.com/sociedad/2020-05$21 /$ los-ninos-tienen-menos-receptores-para-que-entre-elcoronavirus-en-la-nariz.html 
52. Klausner J, Bhatia R. The way to save our kids is to reopen our schools and camps. Daily Beast. May 27, 2020. Accessed June 8, 2020. https://www.thedailybeast.com/the-way-to-save-our-kidsis-to-reopen-our-schools-and-camps

53. Munro A. The missing link? children and transmission of SAR-CoV2, don't forget the bubbles. 2020. CrossRef

54. Zweig D. The case for reopening schools. Wired. May 11, 2020. Accessed May 26, 2020. https://www.wired.com/story/the-casefor-reopening-schools/

55. Halperin D. The case for reopening schools this fall. Washington Post. May 29, 2020. Accessed June 8, 2020. https://www. washingtonpost.com/opinions/2020/05/29/case-reopeningschools-this-fall/

56. Vogel G, Couzin-Frankel J. Should schools reopen? kids' role in pandemic still a mystery. Science. May 4, 2020. Accessed May 26, 2020. https://www.sciencemag.org/news/2020/05/shouldschools-reopen-kids-role-pandemic-still-mystery

57. Gudbjartsson DF, Helgason, Jonsson $\mathrm{H}$, et al. Spread of SARSCoV-2 in the Icelandic Population. N Engl J Med. 2020; NEJMoa2006100. Published online April 14, 2020. CrossRef

58. When easing lockdowns, governments should open schools first. Economist. April 30, 2020. https://www.economist.com/leaders/ 2020/04/30/when-easing-lockdowns-governments-shouldopen-schools-first

59. Coronavirus disease 2019 in children - United States, February 12-April 2, 2020. MMWR Morb Mortal Wkly Rep. 2020;69 (14):422-426. CrossRef. Medline

60. Grifoni A, Weiskopf D, Ramirez SI, et al. Targets of T cell responses to SARS-CoV-2 coronavirus in humans with COVID-19 disease and unexposed individuals. Cell. 2020;181:1-13. CrossRef. Medline

61. Coronavirus in children: risk factors, contagiousness, viral load what we know so far as schools consider reopening. Reuters. May 21, 2020. Accessed June 8, 2020. https://www.scmp.com/ lifestyle/health-wellness/article/3085281/coronavirus-childrenrisk-factors-contagiousness-viral

62. Zhu Y, Bloxham CJ, Hulme KD, et al. Children are unlikely to have been the primary source of household SARS-CoV-2 infections. Preprint. Posted online March 30, 2020. medRxiv. CrossRef

63. Courtemanche C, Garuccio J, Le A, Pinkston J, Yelowitz A. Strong social distancing measures in the United States reduced the COVID19 growth rate. Health Aff. 2020;39(7). CrossRef

64. The Lancet Child Adolescent Health. Pandemic school closures: risks and opportunities. Lancet Child Adolesc Health. 2020;4(5):341 CrossRef. Medline

65. Crawfurd C, Hares S, Sandefur J, Minardi AL. Back to school? Tracking COVID cases as schools reopen. Center for Global Development blog post. May 29, 2020. Accessed June 8, 2020. https://www.cgdev.org/blog/back-school-tracking-covid-casesschools-reopen

66. Pancevski B. Is it safe to reopen schools? These countries say yes. Wall Street Journal. May 31, 2020. Accessed June 8, 2020. https://www.wsj.com/articles/is-it-safe-to-reopen-schools-thesecountries-say-yes-1159092894

67. Reopening schools in Denmark did not worsen outbreak, data shows. Reuters. May 28, 2020. Accessed June 8, 2020. https:// www.reuters.com/article/us-health-coronavirus-denmarkreopening/reopening-schools-in-denmark-did-not-worsenoutbreak-data-shows-idUSKBN2341N7

68. Davidson Sorkin A. The complex question of reopening schools. New Yorker. June 1, 2020. Accessed June 8, 2020. https://www newyorker.com/magazine/2020/06/01/the-complex-questionof-reopening-schools
69. How to reopen America's schools. NY Times. June 6, 2020. Accessed June 8, 2020. https://www.nytimes.com/2020/06/ 06/opinion/coronavirus-schools-reopen. htmlereferringSource= articleShare

70. Cunningham M. Swiss hugging experiment key to answers on COVID-19 risk in kids. Sydney Morning Herald. May 1, 2020 Accessed May 26, 2020. https://www.smh.com.au/national/ australian-experts-look-to-swiss-for-answers-on-covid-19-risk-inkids-20200501-p54oyc.html

71. Redlener I, Redlener KB. Today's children are the pandemic generation. Washington Post. May 12, 2020. Accessed May 26, 2020. https://www.washingtonpost.com/opinions/2020/05/12/ todays-children-are-pandemic-generation-millions-future-is-nowgrim/

72. Woodall C. As hospitals see more severe child abuse injuries during coronavirus, "the worst is yet to come." USA Today. May 13, 2020. Accessed May 26, 2020. https://www.usatoday.com/ story/news/nation/2020/05/13/hospitals-seeing-more-severechild-abuse-injuries-during-coronavirus/31 16395001

73. Hayden S. 'There is violence in the house': children living under lockdown risk abuse the world over. Telegraph. June 3, 2020. Accessed June 8, 2020. https://www.telegraph.co.uk/globalhealth/science-and-disease/violence-house-children-livingafricas-strictest-lockdown-risk/

74. Baron EJ, Goldstein EG, Wallace C. Suffering in silence: how COVID-19 school closures inhibit the reporting of child maltreatment. Preprint. Posted May 17, 2020. SSRN. CrossRef

75. Morrison N. It's not children's education we should worry about, it's their mental health. Forbes. May 15, 2020. Accessed May 26, 2020. https://www.forbes.com/sites/nickmorrison/2020/05/ 15 /its-not-childrens-education-we-should-worry-about-its-theirmental-health/

76. Fowers $A, W a n$ W. A third of Americans now show signs of clinical anxiety or depression, Census Bureau finds amid coronavirus pandemic. Washington Post. May 26, 2020. https://www. washingtonpost.com/health/2020/05/26/americans-withdepression-anxiety-pandemic/?arc404=true

77. Wan W. The coronavirus pandemic is pushing America into a mental health crisis. Washington Post. May 4, 2020. https://www. washingtonpost.com/health/2020/05/04/mental-healthcoronavirus/

78. Jagannathan M. How the stress and isolation of coronavirus could create "a perfect storm" for child abuse and neglect - and what you can do to help. Market Watch. May 7, 2020. Accessed May 26, 2020. https://www.marketwatch.com/story/how-the-stress and-isolation-of-coronavirus-could-create-a-perfect-storm-forchild-abuse-and-neglect-and-what-you-can-do-to-help-2020-0506

79. Rundle AG, Park Y, Herbstman JB, Kinsey EW, Wang YC COVID-19 related school closings and risk of weight gain among children. Obesity (Silver Spring). 2020;28(6): 1008-1009. CrossRef

80. Almaliti F. Life with an autistic child can be difficult. During a pandemic it can be grueling. STAT News. May 15, 2020. Accessed May 26, 2020. https://www. statnews.com/2020/05/15/lifefor-individuals-with-autism-completely-upended-by-covid-19/

81. loannidis JP. A fiasco in the making? As the coronavirus pandemic takes hold, we are making decisions without reliable data. STATNews. March 17, 2020. Accessed May 26, 2020. https:// grwire.com/2020/03/21/a-fiasco-in-the-making-as-thecoronavirus-pandemic-takes-hold-we-are-making-decisionswithout-reliable-data/

82. Friedman TL. A plan to get America back to work. New York Times. March 22, 2020. Accessed May 26, 2020. https://www.nytimes. com/2020/03/22/opinion/coronavirus-economy.html 
83. Bao L, Deng W, Gao H, et al. Reinfection could not occur in SARS$\mathrm{CoV}-2$ infected rhesus macaques. Preprint. Posted online March 14, 2020. bioRxiv. CrossRef

84. Rana P. Can you get Covid-19 twice? Wall Street Journal. May 13, 2020. Accessed May 26, 2020. https://mww.wsj.com/articles/ can-you-get-covid-19-twice-1 1589388593

85. Bienkov A. Germany could issue thousands of people coronavirus 'immunity certificates' so they can leave the lockdown early. Business Insider. March 30, 2020. Accessed May 26, 2020. https://www.businessinsider.com/coronavirus-germany-covid19-immunity-certificates-testing-social-distancing-lockdown2020-3

86. Regalado A. Blood tests show $14 \%$ of people are now immune to covid-19 in one town in Germany. MIT Technology Review. April 9, 2020. Accessed May 26, 2020. https:// www.technologyreview. com/2020/04/09/999015/blood-tests-show-15-of-people-arenow-immune-to-covid-19-in-one-town-in-germany/

87. Tharoor I. Sweden's coronavirus strategy is not what it seems. Washington Post. May 12, 2020. Accessed May 26, 2020. https://www.washingtonpost.com/world/2020/05/12/ swedens-coronavirus-strategy-is-not-what-it-seems/

88. Many covid deaths in care homes are unrecorded. Economist. May 9,2020 . Accessed May 26, 2020. hitps://mww.economist.com/ europe/2020/05/09/many-covid-deaths-in-care-homes-areunrecorded

89. Tracking covid-19 excess deaths across countries; official covid-19 death tolls still under-count the true number of fatalities. Economist. April 16, 2020. Accessed May 26, 2020. https://www.economist. com/graphic-detail/2020/04/16/tracking-covid-19-excessdeaths-across-countries

90. Greenfield D. Sweden cared more about Islamophobia than saving elderly in nursing homes from Coronavirus. FrontPage Mag. May 12, 2020. Accessed May 26, 2020. https://frontpagemag.com/ $\mathrm{fpm} / 2020 / 05 /$ sweden-cared-more-about-islamophobia-savingdaniel-greenfield/

91. Rothschild R. The hidden flaw in Sweden's anti-lockdown strategy. The government expects citizens to freely follow its advice-but not all ethnic groups have equal access to expertise. Foreign Policy. April 21, 2020. Accessed May 26, 2020. https://foreignpolicy. com/2020/04/21/sweden-coronavirus-anti-lockdownimmigrants/

92. Gordon M, Ricketts P, Hutchinson A, Reynolds K, Parson M. Five Republican governors: our states stayed open in the covid-19 pandemic. Here's why our approach worked. Washington Post. May 5 , 2020. Accessed May 26, 2020. https://www.washingtonpost. com/opinions/2020/05/05/republican-governors-our-statesstayed-open-covid-19-pandemic-heres-why-our-approachworked/

93. Halperin DT. The Covid-19 lockdown "natural experiment" that has already been conducted. Preprint. Posted online May 31, 2020. SocArXiv. CrossRef

94. Models project sharp rise in deaths as states reopen. New York Times. May 4, 2020. Updated May 15, 2020. Accessed May 26, 2020. https://www.nytimes.com/2020/05/04/us/coronaviruslive-updates. $h t m l$

95. Rodgers TJ. Do lockdowns save many lives? In most places, the data say no. Wall Street Journal. April 26, 2020. Accessed May 26, 2020. https://www.wsj.com/articles/do-lockdowns-save-manylives-is-most-places-the-data-say-no-1158793091 1

96. Hodgins S. For COVID-19, will the HIC blueprint work in LMICs? Glob Health Sci Pract. 2020;8(2). CrossRef

97. Mehtar S, Preiser W, Lakhe NA, et al. Limiting the spread of COVID-19 in Africa: one size mitigation strategies do not fit all countries. Lancet Glob Health. 2020. Published online April 28, 2020. CrossRef
98. Cash R, Patel V. Has COVID-19 subverted global health? Lancet. 2020. Published online May 5, 2020. CrossRef

99. Oestericher $D$. When lockdown becomes a death sentence: The Coronavirus response in the developing world. The Politic. May 9, 2020. Accessed May 26, 2020. https://thepolitic.org/whenlockdown-becomes-a-death-sentence-the-coronavirus-responsein-the-developing-world/

100. Prasai S. Covid-19 in Nepal: where are we after 9 weeks of lockdown? New Spotlight Nepal. May 19, 2020. https://www. spotlightnepal.com/2020/05/19/covid-19-nepal-where-are-weafter-9-weeks-lockdown/

101. Abi-Habib M, Yasir S. India's coronavirus lockdown leaves vast numbers stranded and hungry. New York Times. March 29, 2020. Accessed May 26, 2020. https://www. nytimes.com/2020/03/ 29/world/asia/coronavirus-india-migrants.html

102. Hohmann J, Alfaro M. Billions are out of work and millions of kids could die from coronavirus's economic fallout. Washington Post. May 15, 2020.

103. Coronavirus: worst economic crisis since 1930s depression, IMF says. BBC News. April 9, 2020. Accessed May 26, 2020. https:// www.bbc.com/news/business-52236936

104. Liffing lockdowns: the when, why and how. Economist. May 23, 2020. https://www.economist.com/leaders/2020/05/23/ lifting-lockdowns-the-when-why-and-how

105. Covid-19 is undoing years of progress in curbing global poverty. Economist. May 23, 2020. Accessed May 26, 2020. https://www. economist.com/international/2020/05/23/covid-19-isundoing-years-of-progress-in-curbing-global-poverty

106. Jan $T, C l e m e n t S$. Hispanics are almost twice as likely as whites to have lost their jobs amid pandemic. Washington Post. May 6, 2020. Accessed May 26, 2020. https://www.washingtonpost. com/business/2020/05/06/layoffs-race-poll-coronavirus/

107. Gathara P. Kenya is turning a public health crisis into a lawand-order one. Washington Post. May 7, 2020. Accessed May 26, 2020. https://www.washingtonpost.com/opinions/ 2020/05/07/kenya-is-turning-public-health-crisis-into-law-andorder-one/

108. Roberts L. Polio, measles, other diseases set to surge as COVID-19 forces suspension of vaccination campaigns. Science. April 9, 2020. Accessed May 26, 2020. https://www.sciencemag.org/ news/2020/04/polio-measles-other-diseases-set-surge-covid19-forces-suspension-vaccination-campaigns

109. Ford L. Millions predicted to develop tuberculosis as result of Covid-19 lockdown. Guardian. May 6, 2020. Accessed May 26, 2020. https://www.theguardian.com/global-development/ 2020/may/06/millions-develop-tuberculosis-tb-covid-19lockdown

110. WHO estimates malaria deaths could double because of interruptions caused by COVID-19. HEALIO Infectious Disease News. April 20, 2020. Accessed May 26, 2020. https://www. healio.com/infectious-disease/emerging-diseases/news/ online/\%7Bc34b63f9-b383-4a42-8162-527965c684fa\%7D/ who-estimates-malaria-deaths-could-double-because-ofinterruptions-caused-by-covid-19

111. Roberton T, Carter ED, Chou VB. Early estimates of the indirect effects of the COVID-19 pandemic on maternal and child mortality in low-income and middle-income countries: a modelling study. Lancet Glob Health. 2020. Published online May 12, 2020. CrossRef

112. Santoli JM, Lindley MC, DeSilva MB, et al. Effects of the COVID-19 pandemic on routine pediatric vaccine ordering and administration-United States, 2020. MMWR Morb Mortal Wkly Rep. 2020;69:591-593. CrossRef. Medline

113. Santoshini $S$. Family planning efforts upended by the coronavirus. Foreign Policy. May 13, 2020. Accessed June 8, 2020. https:// 
foreignpolicy.com/2020/05/13/india-family-planningupended-coronavirus-women-sexual-reproductive-health/

114. Pancevski B. Forgotten pandemic offers contrast to today's coronavirus lockdowns. Wall Street Journal. April 24, 2020. Accessed May 26, 2020. https://www.wsj.com/articles/forgottenpandemic-offers-contrast-to-todays-coronavirus-lockdowns11587720625

115. Draulans D. 'Finally, a virus got me.' Scientist who fought Ebola and HIV reflects on facing death from COVID-19. Science. May 8 , 2020. Accessed May 26, 2020. https://www.sciencemag.org/ news/2020/05/finally-virus-got-me-scientist-who-fought-ebolaand-hiv-reflects-facing-death-covid-19

116. Harding L. 'Weird as hell': the Covid-19 patients who have symptoms for months. Guardian. May 15, 2020. Accessed May 26, 2020. https://www.theguardian.com/world/2020/may/15/ weird-hell-professor-advent-calendar-covid-19-symptoms-paulgarner

117. Rao A. 'People are dying at home': virus fears deter seriously ill from hospitals. Guardian. May 6,2020. Accessed May 26, 2020. https://wuw.theguardian.com/world/2020/may/06/dying-athome-non-covid-19-hospitals-coronavirus

118. Hafner K. Fear of Covid-19 leads other patients to decline critical treatment. NY Times. May 25, 2020. Accessed June 8, 2020. https://www.nytimes.com/2020/05/25/health/coronaviruscancer-heart-treatment.html

119. Kendrick M. COVID. 'with' 'of' or 'because of'. Malcolmkendrick. org blog. April 6, 2020. Accessed May 26, 2020. https://drmal colmkendrick.org/2020/04/06/covid-with-of-or-because-of/

120. 5 common sense reasons why the Africa continent is escaping the worst of the pandemic. Africa Expat Wives Club blog. May 22, 2020. Accessed June 8, 2020. https://africaexpatwivesclub. wordpress.com/2020/05/22/5-common-sense-reasons-whythe-africa-continent-is-escaping-the-worst-of-the-pandemic/

121. Miller A, Reandelar MJ, Fasciglione K, Roumenova V, Li Y, Otazu $\mathrm{GH}$. Correlation between universal BCG vaccination policy and reduced morbidity and mortality for COVID-19: an epidemiological study. Preprint. Posted online March 28, 2020. medRxiv. CrossRef

122. King A. An old TB vaccine finds new life in coronavirus trials. The Scientist. May 4, 2020. Accessed May 26, 2020. https://www. the-scientist.com/news-opinion/an-old-tb-vaccine-finds-new-lifein-coronavirus-trials-67504

123. Moyer MW. Could 'innate immunology' save us from the coronavirus? NY Times. May 1, 2020. Accessed June 8, 2020. https:// www.nytimes.com/2020/05/01/opinion/sunday/coronavirusvaccine-innate-immunity.html

124. Walker D, Chi YL, Poli F, Chalkidou K. A tool to estimate the net health impact of COVID-19 policies. Center for Global Development blog. May 26, 2020. Accessed June 8, 2020. hitps://www.cgdev.org/blog/tool-estimate-net-health-impactcovid-19-policies

125. Barasa E, Mothupi MC, Guleid F, et al. DFID Policy Brief: Rapid Review of Physical Distancing in Africa. Department for International Development. May 15, 2020.

126. OHH. 6 months of coronavirus lockdown could mean 31 million more cases of domestic violence, UN says. CBS News. April 28, 2020. Accessed May 26, 2020. https://www.cbsnews.com/ news/domestic-violence-additional-31-million-cases-worldwide/

127. Bosman J. Domestic violence calls mount as restrictions linger: 'no one can leave'. New York Times. May 15, 2020. Accessed May 26, 2020. https://www.nytimes.com/2020/05/15/us/ domestic-violence-coronavirus.html

128. Zakaria R. Domestic violence and coronavirus: hell behind closed doors. The Nation. April 2, 2020. Accessed June 8, 2020. https:// www.thenation.com/article/society/domestic-violencecoronavirus/

129. Adam D. The hellish side of handwashing: how coronavirus is affecting people with OCD. The Guardian. March 29, 2020 Accessed May 26, 2020. https://www.theguardian.com/society/ 2020/mar/13/why-regular-handwashing-can-be-bad-advicefor-patients

\section{Peer Reviewed}

Received: May 19, 2020; Accepted: May 19, 2020; First published online: June 17, 2020

Cite this article as: Halperin DT. Coping with COVID-19: learning from past pandemics to avoid piffalls and panic. Glob Health Sci Pract. 2020; 8(2):155-165. https://doi.org/10.9745/GHSP-D-20-00189

(C) Halperin. This is an open-access article distributed under the terms of the Creative Commons Attribution 4.0 International License (CC BY 4.0), which permits unrestricted use, distribution, and reproduction in any medium, provided the original author and source are properly cited. To view a copy of the license, visit http://creativecommons.org/licenses/by/4.0/. When linking to this article, please use the following permanent link: https://doi.org/ 10.9745/GHSP-D-20-00189 